\title{
Variations in Some Electrolytes in Tilapia guineensis Exposed to Dimethoate (DMC)
}

\author{
Alalibo, O. O. ${ }^{1^{*}}$, Gabriel, U.U. ${ }^{2}$, Edun O. $\mathrm{M}^{3}$, Akinrotimi O.A ${ }^{4 *}$ \\ ${ }^{1,2}$ Department of Fisheries and Aquatic Environment, Faculty of Agriculture, Rivers State University, Nkpolu- \\ Oroworukwo, Port Harcourt, Nigeria \\ ${ }^{3}$ African Regional Aquaculture Center/ Nigerian Institute for Oceanography and Marine Research, P.M.B. \\ 5122, Port Harcourt, Nigeria
}

*Corresponding Author: Akinrotimi O.A, African Regional Aquaculture Center/ Nigerian Institute for Oceanography and Marine Research, P.M.B. 5122, Port Harcourt, Nigeria

\begin{abstract}
Variations in selected electrolytes such as Sodium $\left(\mathrm{Na}^{+}\right)$, Potassium $\left(\mathrm{K}^{+}\right)$, Chloride $\left(\mathrm{Cl}^{-}\right)$and Calcium $\left(\mathrm{Ca}^{2+}\right)$ in the plasma of juveniles and adult sizes of Tilapia guineensis exposed to dimethoate (DMC) at the concentrations of 0.00 (control), 1.00, 1.50, 2.00, 2,50 and $3.00 \mathrm{mg} / \mathrm{L}$ were conducted to assess the variations in electrolytes alterations in fish exposed to Dimethoate (DMC) under laboratory conditions. A total of seventy-five juvenile sizes and seventy-five adult sizes of T.guineensis were utilized for this trial. Results from the examination demonstrated that significant alterations comparable to the control values were observed in all the electrolytes under consideration. These alterations were pronounced in juvenile fish than the adult sizes.
\end{abstract}

Keywords: Electrolytes, Chemical, Biochemical, Osmoregulation.

\section{INTRODUCTION}

Almost Everywhere in different parts of the world the aquatic environment is continuously being loaded with contaminants released by urban communities and industries [1]. In many of these places, myriads of organic trace pollutants, such as polychlorinated biphenyls, organ chlorine pesticides, hydrocarbons and polychlorinated dibenzofurans have been produced and, in part, discharged into land and waters [2]. For certain decades now, humanity has turned out to be mindful of the capability of the impact of these synthetic compounds and their potential dangers for oceanic and earthly biological systems specifically. A definitive part of the bargain is the aquatic condition, either because of direct release or to hydrologic and climatic procedures [3-4].

The presence of zenobiotic substances in a fragment of an aquatic system does not on its own show damaging impacts. Associations must be set up between levels of presentation, inside degrees of tissue destruction, collection, and early antagonistic impacts. Thus, the introduction, destiny and, particularly, impacts of contaminants in the aquatic environment on the osmoregulation of fish should be broadly considered. Conversely, appraisals of electrolytes in the blood of fish are great pointers of evaluating the wellbeing status of fish in ecotoxicology [5-6]. The electrolytes are substances which impact the circulation and maintenance of water around the arrangement of an individual [7]. In view of this, Gabriel et al. [8] reported that sodium and potassium are the most significant osmotically viable electrolytes and consequently the most considered.

Others of significant importance are chloride and calcium. Calcium is available in the body in larger amount than some other mineral component. It is available in the bones as stores of calcium phosphate. It is likewise present in little focuses in body liquids. The ionized calcium in the body assists in blood coagulation and keeping up the typical volatility of muscles [9-10]. Estimation of hematological parameters gives a sign of the poor or great state of fish wellbeing more quickly than other normally estimated parameters, as they react all the more promptly to changes in the natural condition [11-12]. Changes in electrolyte levels show the activity of an assortment of homeostatic mechanisms in the assemblage of fish and assume an important job in osmoregulation and homeostasis. This paper accordingly evaluates the impacts of dimethoateon on selected electrolytes in Tilapia guineensis, a commonly cultured fish in Nigeria. 


\section{Materials AND Methods}

\subsection{Experimental Location}

The study was carried out at African Regional Aquaculture Center, (an outstation of) Nigerian Institute for Oceanography and Marine Research, Buguma, Rivers State, Nigeria.

\subsection{Trial Fish}

Seventy-five each of adult and juvenile sizes of $T$. guineensis were sourced from recruitment ponds in the station during the low tide. The fishes were shipped in six open 501 plastic compartments to the laboratory and acclimated for a period of seven days.

\subsection{Arrangement of Test Solutions and Exposure of Fish.}

The pesticide dimethoate (DMC) utilized in this trial was purchased from a business outlet in Port Harcourt, Nigeria. T. guineensis fish were exposed to the substance at the concentrations of 0.00 (for control), 1.00, 1.50, 2.00, 2.50 and $3.00 \mathrm{mg} / \mathrm{L}$ in triplicates. Five fishes were randomly dispersed into each test tank. The examination went on for a time of 14 days. The water in the tanks was reestablished day by day. The fish were fed twice every day at $3 \%$ body weight with a commercial feed.

\subsection{Determination of Blood Serum Electrolytes}

At the end of the experimental period, $2 \mathrm{ml}$ of fresh blood sample was collected by making a caudal puncture with the help of a fine needle and syringe, and poured into heparinized sample bottles. Serum was separated by centrifugation at 10,000rpm for 5-8 minutes in TG20-WS Tabletop High Speed Laboratory Centrifuge. Serum electrolytes such as $\mathrm{Na}+\mathrm{K}+, \mathrm{Ca}_{2}+$ and $\mathrm{Cl}^{-}$were determined by using Hitachi 902 automatic analyzer (Japan), following the method described by Gabriel et al.(2012). All the tests were performed in triplicates.

\subsection{Statistical Analysis}

All the data were expressed as mean and standard deviation of mean. The statistical package, SPSS Version 22 was used for the data analysis. The means were separated using two-way ANOVA and the two means were considered significant at $5 \%(\mathrm{P}<0.05)$.

\section{RESULTS}

The resultant impacts of DMC on the electrolytes in the plasma of T.guineensis juveniles are introduced in Table 1. It was seen that sodium $(\mathrm{Na}+)$ and $\mathrm{K}+$ expanded with expanding concentrations of the pesticides. Likewise $\mathrm{Ca} 2+$ diminished essentially when contrasted with the control, while Clwas within a similar scope of 16.0-19.0 (Table 1). In the adult fish treated with DMC, there was huge variety over the concentrations toxicants. At the same time $\mathrm{Na}+$ and $\mathrm{K}+$ expanded and crested at 3.00 $\mathrm{mg} / \mathrm{L}$ of the contaminants (Table 2 ).

Table1. Effects of Dimethoate (DMC) on the Electrolytes ions in the Plasma of T.guineensis Juveniles $(M e a n \pm S D)$

\begin{tabular}{|c|c|c|c|c|}
\hline Conc.(mg/L) & $\mathbf{N a}^{+}$ & $\mathbf{C a}^{\mathbf{2}}$ & $\mathbf{K}^{+}$ & $\mathbf{C l}^{\mathbf{}}$ \\
\hline 0.00 & $42.30 \pm 1.01^{\mathrm{a}}$ & $34.50 \pm 2.01^{\mathrm{e}}$ & $2.40 \pm 0.22^{\mathrm{a}}$ & $16.00 \pm 1.08^{\mathrm{a}}$ \\
\hline 1.00 & $46.50 \pm 2.45^{\mathrm{a}}$ & $28.88 \pm 2.02^{\mathrm{d}}$ & $3.80 \pm 1.15^{\mathrm{a}}$ & $17.00 \pm 1.34^{\mathrm{a}}$ \\
\hline 1.50 & $53.80 \pm 1.20^{\mathrm{b}}$ & $24.80 \pm 1.05^{\mathrm{c}}$ & $5.60 \pm 0.07^{\mathrm{b}}$ & $17.00 \pm 1.28^{\mathrm{a}}$ \\
\hline 2.00 & $65.90 \pm 1.99^{\mathrm{c}}$ & $20.70 \pm 2.09^{\mathrm{c}}$ & $7.70 \pm 0.05^{\mathrm{b}}$ & $16.00 \pm 1.19^{\mathrm{a}}$ \\
\hline 2.50 & $67.50 \pm 1.54^{\mathrm{c}}$ & $15.50 \pm 1.04^{\mathrm{b}}$ & $11.90 \pm 0.04^{\mathrm{c}}$ & $18.00 \pm 2.53^{\mathrm{a}}$ \\
\hline 3.00 & $76.80 \pm 2.21^{\mathrm{d}}$ & $8.90 \pm 1.08^{\mathrm{a}}$ & $12.20 \pm 0.12^{\mathrm{c}}$ & $19.00 \pm 1.95^{\mathrm{a}}$ \\
\hline
\end{tabular}

Means in the same column with different superscripts are significantly different $(\mathrm{p}<0.05)$

Table2. Effects of Dimethoate (DMC) on the Electrolytes ions in the Plasma of T.guineensis (Mean $\pm S D$ )

\begin{tabular}{|c|c|c|c|c|}
\hline Conc.(mg/L) & $\mathbf{N a}^{+}$ & $\mathbf{C a}^{\mathbf{2}}$ & $\mathbf{K}^{+}$ & $\mathbf{C l}^{\mathbf{}}$ \\
\hline 0.00 & $42.30 \pm 1.01^{\mathrm{a}}$ & $34.50 \pm 2.01^{\mathrm{c}}$ & $2.40 \pm 0.22^{\mathrm{a}}$ & $16.00 \pm 1.01^{\mathrm{a}}$ \\
\hline 1.00 & $44.76 \pm 2.11^{\mathrm{a}}$ & $33.11 \pm 2.44^{\mathrm{c}}$ & $2.60 \pm 1.18^{\mathrm{a}}$ & $16.00 \pm 1.02^{\mathrm{a}}$ \\
\hline 1.50 & $46.21 \pm 1.13^{\mathrm{a}}$ & $30.99 \pm 1.43^{\mathrm{b}}$ & $3.20 \pm 1.02^{\mathrm{b}}$ & $16.00 \pm 1.41^{\mathrm{a}}$ \\
\hline 2.00 & $50.12 \pm 1.54^{\mathrm{b}}$ & $28.88 \pm 2.34^{\mathrm{a}}$ & $4.80 \pm 1.78^{\mathrm{b}}$ & $15.00 \pm 1.49^{\mathrm{a}}$ \\
\hline 2.50 & $54.65 \pm 1.19^{\mathrm{b}}$ & $27.86 \pm 1.13^{\mathrm{a}}$ & $6.30 \pm 1.88^{\mathrm{c}}$ & $15.00 \pm 2.12^{\mathrm{a}}$ \\
\hline 3.00 & $58.88 \pm 2.05^{\mathrm{c}}$ & $25.17 \pm 1.43^{\mathrm{a}}$ & $8.30 \pm 1.01^{\mathrm{c}}$ & $16.00 \pm 1.06^{\mathrm{a}}$ \\
\hline
\end{tabular}

Means in the same column with different superscripts are significantly different $(\mathrm{p}<0.05)$ 


\section{DISCUSSION}

Electrolytes are required for osmoregulatory purposes in the body arrangement of a living oranisms; in this manner electrolyte balance in the body of a living being is important for the ordinary capacity of cells and organs. Gabriel et al. [13] uncovered that the fundamental capacity of electrolytes in the body incorporates the control of liquid circulation, intracellular and extracellular acido-essential balance to accomplish appropriate support of osmotic weight of body liquids and typical neuro-solid irritability. In this way, adjustments of the electrolyte parity of a life form would unfavorably influence the living being concerned. The outcomes got in this trial indicate that the example shown by electrolytes in the plasma of T.guineensis exposed to various concentrations of the chemicals was concentration gradient of the toxicant.

This investigation showed changes in electrolytes of fish treated with different concentrations of DMC. Likewise, this trial indicated noteworthy changes in the electrolytes level in the plasma of the two sizes of T.guineensis. There were critical changes $(\mathrm{p} \leq 0.05)$ in all the plasma electrolytes in the fish, aside from chlorides that did not change at the different concentrations of the pesticide. Plasma electrolytes are known to vacillate in light of different contaminants [4]. These aggravations in homeostasis are exacerbated by toxins and prove by changed plasma particle fixation [8]. The electrolyte profiles of fish in the present examination indicated variances because of exposure to DMC. Besides, the variances in electrolytes analyzed could be connected to heart stress [14]. Decrease of $\mathrm{Na}+$ particle level may influence the heart capacities and cause neurotoxic harm to the focal sensory system (CNS) of fish [15]. On the other hand, Mishra et.al. [16] opined that synthetic compounds, for example, cypermethrin adjust nerve motivation goes along nerves of vertebrates and fish especially. The nerves become quickly porous to sodium molecules, therefore enabling it to stream into nerves. It likewise postpones the end of the entryway that permits the sodium stream [17].

Commonly, synthetic compounds have been accounted for a gigantic influence the penetrability of the sodium voltage relying upon directs in the sensory cells [18]. The change of electrolytes in toxicant exposed fish uncovered the fact toxins could obstruct the normal function of these electrolytes. For example, sodium and potassium are fundamental for the movement of numerous compounds and have been embroiled in the movement of Adenosine triphosphate which takes part in a few metabolic procedures [19]. Like calcium, potassium and sodium particles assist the cell in the upkeep of ordinary fractiousness of the heart, muscles and nerves just as particular porousness of cell layer [20]. The noteworthy variety $(\mathrm{P}<0.05)$ saw in the electrolytes in this investigation might be related with uneven characters prompting raised solid exercises and adjustments in ionic transitions over the muscle layer [21].

\section{CONCLUSION}

This trial has showed that DMC caused huge modifications in the electrolyte profiles of the exposed T.guineensis, a reasonable sign that their utilization in the fields and water condition might be a risk to amphibian biota. Reasonable and ecological well disposed farming systems must be supported in different parts of the nation to keep these chemical from finding their way into the aquatic environment.

\section{REFERENCES}

[1] Shibata, M., Hakuno, F., Yamanaka, D., Okajima, H., Fukushima, T., Hasegawa, T. \& Sakoda, H. (2010).Paraquat-induced oxidative stress represses phosphatidylinositol 3-kinase activities leading to impaired glucose uptake in 3T3-L1 adipocytes. Journal of Biological Chemistry, 285(27), 20915-20925.

[2] Rao, J. V. (2006). Toxic effects of novel organophosphorus insecticide (RPR-V) on certain biochemical parameters of euryhaline fish, Oreochromismossambicus. Pesticide Biochemistry and Physiology, 86(2), 78-84.

[3] Ray, S., Sengupta, A., \& Ray, A. (2007).Effects of paraquat on anti-oxidant system in rats. Ecotoxicology and Environmental Safety 72, 1727-1733.

[4] Ayanda, O. I., Oniye, S. J., Auta, J. A., Ajibola, V. O., \& Bello, O. A. (2015). Responses of the African catfish Clariasgariepinus to long-term exposure to glyphosate-and paraquat-based herbicides. African journal of aquatic science, 40(3), 261-267.

[5] David M., Shivakumar H.B., Shivakumar R., Mushigeri S.B. \& Ganthi B.H. (2003). Toxicity evalution of cypermethrin and its effect on oxygen consumption of thefresh water fish, Tilapia mossambica. Indian Journal of Environmental Toxicology, 13, 99-102 
[6] Nte, M.E., \& Akinrotimi, O.A. (2011). Biochemical changes in black jaw tilapia (Sarotherodon melanotheron) treated with sub lethal levels of industrial effluents. Advances in Agriculture, Science and Engineering Research, 1(2), 25-33.

[7] Akinrotimi, O.A.,Opara, J.Y.,\& Ibemere, I.F. (2012). Changes in haematological parameters of Tilapia guineensis exposed to different water $\mathrm{pH}$ environment. Innovation in Science and Engineering, 2, 9-14.

[8] Gabriel, U.U., Uedeme-Naa, B., and Akinrotimi, O.A. (2011). Pollutant induced altered behaviours in fish: A review of selected literature. Journal of Technology and Education in Nigeria (JOTEN), 16(1), 9-23.

[9] Linde, A. R., Sanchez-Galan, S. and Garcia-Vazquez, E. (2004). Heavy metal contamination of European eel (Anguilla anguilla) and brown trout (Salmo trutta) caught in wild ecosystems in Spain. Journal of food protection, 67(10), 2332-2336.

[10] Banaee, M., Davoodi, M. H. \& Zoheiri, F. (2013). Histopathological changes induced by paraquat on some tissues of gourami fish (Trichogastertrichopt) Journalof Marine Science and Technology Research, 12(2), 21-27.

[11] Ayoola, S. O. (2008). Toxicity of glyphosate herbicide on Nile tilapia (Oreochromisniloticus) juvenile. African Journal of Agricultural Research,3(12), 825-834.

[12] Ayuba, V. O., Iyakwari, S. P. \& Oyeniyi, M. E. (2013). Acute Toxicity of Formalin on Clariasgariepinus Juveniles. Publication of Nasarawa State University, 9(1), 21-28

[13] Gabriel, U.U., Akinrotimi, O.A., and Ariweriokuma, S.V. (2012). Alterations of selected electrolytes in organs of African catfish, Clarias gariepinus treated with cypermethrin. Advances in students Research, 2(1), 53-60.

[14] Bansal, S., Lindenfeld, J \& Schrier, R. W. (2009). Sodium retention in heart failure and cirrhosis.Circulation: Heart Failure, 2(4), 370-376.

[15] Benli, A.K. (2010).Acute toxicity and histopathological effects of biochemical parameters of euryhaline fish, Oreochromis mossambicus. Crop Protect, 14,593-600.

[16] Dang, A., Silburn, M., Craig, I., Shaw, M. and Foley, J. (2016).Wash off of residual photosystem II herbicides from sugar cane trash under a rainfall simulator.Journal of agricultural and food chemistry, 64(20), 3967-3974.

[17] De Moraes, F.D., Venturini, F.P., Cortella, L.R.X., Rossi, P.A. and Moraes, G. (2013). Acute toxicity of pyrethroid-based insecticides in the Neotropical freshwater fish Brycon amazonicus". Ecotoxicol. Environ. Contam. 8(2), 59-64.

[18] Inyang, I.R. (2008). Haematological and biochemical responses of Clarias gariepinus to diazinon. Ph.D thesis, Rivers State University of Science and Technology. Port Harcourt, Nigeria.

[19] Inyang, I.R. and Patani, D.E. (2015). Haematological aberrations and electrolyte Stabilization in Heterobranchus bidorsalis induced by rhonasate 360SL containing glyphosate. Nigerian Journal of Agriculture, Food and Environment, 11(3):28-31

[20] Inyang, I.R., Obidiozo, OZ. and Izah, S.C. (2016a). Effects of Lambda cyhalothrin on protein and Albumin content in the kidney and liver of Parpohiocephalus obscurus. EC Pharmacology and Toxicology, 2(3): 148-153

Citation: Akinrotimi O.A, et.al, "Variations in Some Electrolytes in Tilapia guineensis Exposed to Dimethoate (DMC)”. International Journal of Innovative Studies in Aquatic Biology and Fisheries, 5(4), pp.12-15.http://dx.doi.org/10.20431/2454-7670.0504003

Copyright: (C) 2019 Authors. This is an open-access article distributed under the terms of the Creative Commons Attribution License, which permits unrestricted use, distribution, and reproduction in any medium, provided the original author and source are credited. 